\author{
Michal BARTOŠ${ }^{1}$, Ivan KURIC ${ }^{2}$, Martin BOHUŠÍK ${ }^{3}$, Vladimír STENCHLÁK ${ }^{4}$ \\ Opiekun naukowy: Vladimír BULEJ ${ }^{5}$
}

DOI: https://doi.org/10.53052/9788366249837.30

\title{
PRZEGLĄD KONSTRUKCJI ROBOTÓW MAJĄCYCH RÓWNOLEGŁE STRUKTURY KINEMATYCZNE
}

\begin{abstract}
Streszczenie: W niniejszym artykule skupiono się na idei oraz bieżącym stanie wiedzy dotyczącym robotów mających równoległe struktury kinematyczne. We wstępie do publikacji opisano istniejące roboty mające równoległą strukturę kinematyczną. Przedstawiono zasady ich działania oraz dokonano porównania robotów z szeregową strukturą kinematyczną, a także opisano zalety poszczególnych struktur. W kolejnym rozdziale artykułu, przeprowadzono analizę poszczególnych konstrukcji oraz dokonano podziału mechanizmów równoległych. Ponadto, w pracy opisano najbardziej znane oraz niestosowane konstrukcje robotów o równoległej strukturze kinematycznej. W ostatniej części artykułu opisano przykłady użycia robotów mających równoległą strukturę kinematyczną oraz ich spodziewany rozwój w najbliższej przyszłości.
\end{abstract}

Słowa kluczowe: roboty, równoległe układy kinematyczne, robot delta, hexapod, DOF

\section{AN OVERVIEW OF ROBOTS WITH PARALLEL KINEMATIC STRUCTURE}

Summary: The article is focused on the issue and the current state of knowledge of robots with a parallel kinematic structure. The introduction of the article describes robots with a parallel kinematic structure. Their principle and a comparison between robots with a serial kinematic structure is made and the advantages of individual structures are described. In the next chapter of the article, the analysis of the construction and the division of parallel mechanisms is performed. The article describes the most well-known and unused constructions of robots with a parallel kinematic structure. In the last part, the article focuses on and presents examples of

\footnotetext{
${ }^{1}$ Ing., University of Zilina, Faculty of Mechanical Engineering, Department of Automation and Production Systems: michal.bartos@fstroj.uniza.sk

${ }^{2}$ prof. Dr. Ing., University of Bielsko-Biala, Faculty of Mechanical Engineering and Computer Science, Department of Industrial Engineering: kuric.ivan@gmail.com

${ }^{3}$ Ing., University in Žilina, Faculty of Mechanical Engineering, Department of Automation and Production Systems, e-mail: martin.bohusik@fstroj.uniza.sk

${ }^{4}$ Ing., University of Žilina, Faculty of Mechanical Engineering, Department of Automation and Production Systems, e-mail:milan.saga2@fstroj.uniza.sk,martin.bohusik@fstroj.uniza.sk ${ }^{5}$ Assoc.-prof., Ing., PhD., University in Žilina, Faculty of Mechanical Engineering, Department of Automation and Production Systems, e-mail: vladimir.bulej@fstroj.uniza.sk
} 
the usage of robots with a parallel kinematic structure and their expected development in the future.

Keywords: robots, parallet kinematics, delta robot, hexapod, DOF

\section{Introduction}

Robots using a parallel kinematic structure have different numbers of arms with active and passive joints and links that carry the load in parallel. Parallel robots can transfer higher loads with higher accuracy, higher speed at lower total robot weight. However, the main disadvantage is that the working space of parallel robots is significantly limited compared to equivalent serial robots. Parallel robots are used in the construction of industrial robots, aircraft and automotive simulators, machine tools, medical equipment, in the civilian sectors and the like. [1]In the case of the parallel kinematics strusture mechanisms shown in Fig.1 with a corresponding number of degrees of freedom, the relative spatial position of the end member (TCP point) is determined by coordinated parallel linear or rotational movements of a number of active and passive linear guides or rotating members. [2]

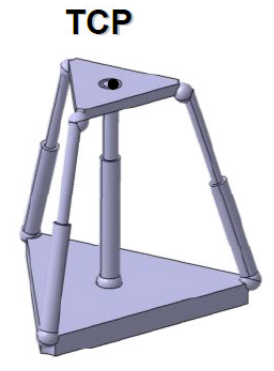

a)

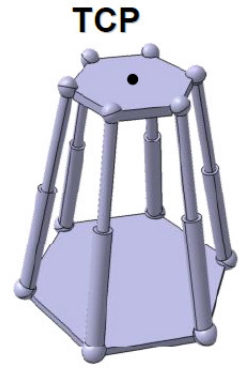

b)

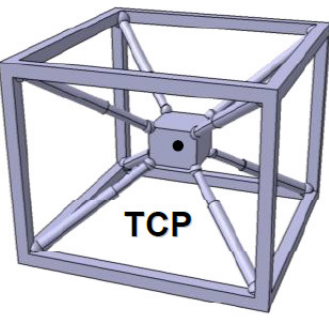

c)

Figure 1. 3D models of robots with parallel kinematic structure, a) tripod, b) hexapod, d) oktapod [3]

\section{Robots with parallel kinematic structure}

There are several definitions of the mechanism with parallel kinematic structure, the basic definition says: "A general parallel manipulator is a mechanism with a closed kinematic chain, the end effector or platform of which is connected to the base by several (at least two) independent kinematic chains."[4]

Parallel mechanisms are interesting due to some of their properties:

- at least two chains allow us to distribute the load evenly throughout the chain;

- minimum number of controls; 
- the minimum number of sensors needed to control the mechanism in a closed loop;

- when the actuators are locked, the manipulator and its effector remain in position; this is an important security aspect for certain applications, such as medical robotics.

According to another definition, parallel robots can be defined as robots that are formed by an end effector with n-degrees of freedom, and a fixed base connected by at least two independent kinematic chains where the control takes place by n-drives.[4]

Thus, a parallel robot and a parallel manipulator can be called a mechanism using the principle of parallel kinematics. These kinematic chains together control one end point - the Tool Centre Point(TCP point). There are currently several designs and drive options. The most well-known parallel robots and manipulators include the so-called delta robot.

The following table compares some of the properties of serial and parallel robots.

Table 1. Comparison of properties of robots with serial and parallel kinematics structure [5]

\begin{tabular}{|c|c|c|}
\hline Parameter & Serial kinematic structure & Parallel kinematic structure \\
\hline $\begin{array}{l}\text { Mechanical } \\
\text { architecture }\end{array}$ & + simple architecture & - More complex architecture \\
\hline Payload & $\begin{array}{l}\text { - Higher weight, worse } \\
\text { dynamic properties, higher } \\
\text { flexibility }\end{array}$ & $\begin{array}{l}\text { + Lower weight, better dynamic } \\
\text { properties, higher rigidity of the } \\
\text { robot }\end{array}$ \\
\hline $\begin{array}{l}\text { Accuracy, } \\
\text { repeatability }\end{array}$ & $\begin{array}{l}\text { - Loss of accuracy and } \\
\text { repeatability }\end{array}$ & $\begin{array}{l}\text { + Easier to achieve greater } \\
\text { accuracy and repeatability }\end{array}$ \\
\hline $\begin{array}{l}\text { Actuator } \\
\text { placement }\end{array}$ & $\begin{array}{l}\text { - Worse dynamic properties } \\
\text { - Greater robustness of the } \\
\text { manipulator } \\
\text { - The need to run cabling } \\
\text { throughout the mechanical } \\
\text { structure }\end{array}$ & $\begin{array}{l}\text { + Better dynamic properties } \\
\text { + Lighter construction } \\
\text { + Possibility to spatially separate } \\
\text { the actuator }\end{array}$ \\
\hline Workspace size & + relatively large workspace & $\begin{array}{l}\text { - The workspace is more } \\
\text { complicated due to the more } \\
\text { complex mechanical construction }\end{array}$ \\
\hline Kinematics & $\begin{array}{l}\text { direct - simple } \\
\text { inverse - complex }\end{array}$ & $\begin{array}{l}\text { inverse - simple } \\
\text { direct - complex }\end{array}$ \\
\hline Axle load & $\begin{array}{l}\text { - high - each axis carries the } \\
\text { same weight }\end{array}$ & + low - weight division \\
\hline Weight & - high & + low \\
\hline Load capacity & - average & + high - weight division \\
\hline
\end{tabular}

\subsection{Construction of a robotic device with parallel kinematic structure}

During the construction and design it is necessary to pay attention to some properties of parallel kinematic structures. With parallel robots, the total number of degrees of 
freedom is lower than the number of degrees of freedom in the joints, so many joints are passive. Kinematic chains are formed by joining several kinematic pairs. The following kinematic pairs shown in Fig. 2 below are most commonly used to form kinematic chains.

In the case of parallel robots, the end point is the so-called mobile platform (hereinafter referred to as the platform). The platform usually serves to support the attached end effector and is connected to the base by a number of parallel arranged arms (guide chains).
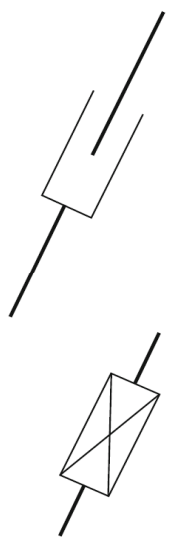

$\mathrm{T}$ - translational
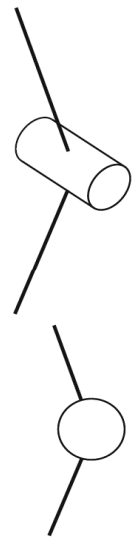

$\mathrm{R}$ - rotational
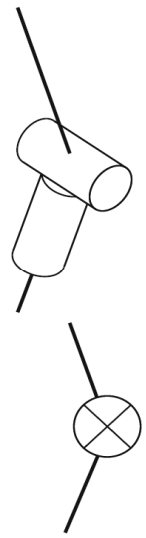

$\mathrm{U}$ - universal
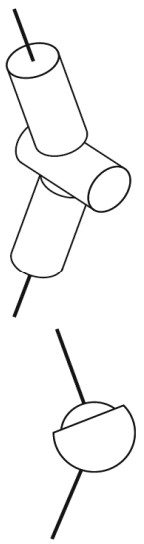

$\mathrm{S}$ - spherical

Figure 2. Kinematic pairs used in parallel kinematics structures [6]

The whole structure contains at least one closed kinematic chain with at least two branches. Shifts in the legs cause the platform to shift, as shown in Fig. 3. Platform movements are defined by trigonometric functions of the direct and inverse kinematics tasks depending on the geometry of the mechanism, the type of joints, the number of arms and their kinematic arrangement.
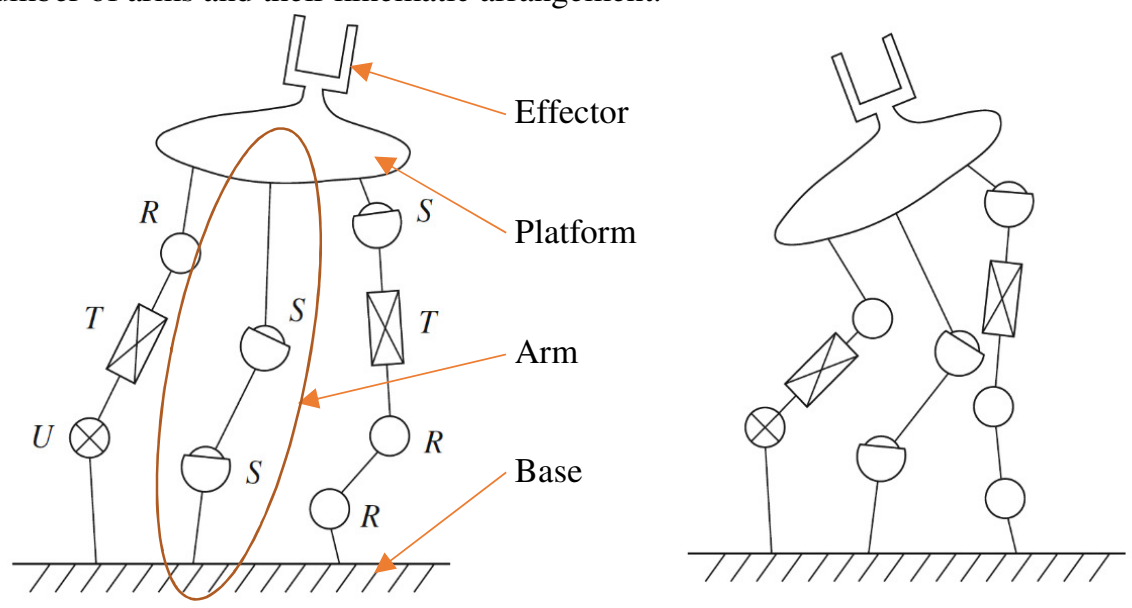

Figure 3. Basic structure of robot with parallel kinematic structure 


\subsection{Number of degrees of freedom}

When designing a robot, it is necessary to calculate the number of degrees of freedom, the calculation is based on the technical design of the robot and is expressed by the Chebyshev-Grübler-Kutzbach criterion (1) [7]:

$$
D o F=\lambda(\mathrm{n}-\mathrm{g}-1)+\sum_{i=1}^{j} f_{i}
$$

where:

DoF - number of freedom of mechaniszm

$\lambda$ - number of freedom of body ( 6 for 3D space, 3 pre 2D space)

$\mathrm{n}$ - number of conections in mechaniszm including base

$\mathrm{g}-$ number of joints (kinematic pairs)

$f_{i}-$ relative degree of freedom allowing the joint to move in space

This criterion only applies if there are no passive degrees of freedom in the mechanism (those that do not transmit force or torque to the end platform but have the ability to move. Therefore, an extended criterion (2) is defined [7]:

$$
D o F=\lambda(\mathrm{n}-\mathrm{g}-1)+\sum_{i=1}^{j} f_{i}-f_{p}
$$

where: $\quad f_{p}$ - number of passive degrees of freedom of the mechanism

To clearly determine the position of the end effector in the robot's workspace, we need to know the coordinates of the TCP point. For the description of the position of the TCP point, the Cartesian coordinates $\mathbf{X}, \mathbf{Y}, \mathbf{Z}$ are most often used for parallel mechanisms, for the position in the given axes and the angles $\boldsymbol{\alpha}, \boldsymbol{\beta}, \boldsymbol{\gamma}$ for the description of the rotation around these axes. The axes makes degrees of freedom for feed (translation) and rotation. The degrees of freedom created with respect to the axes will therefore be referred to as:

- $\operatorname{Trans}(\mathrm{X})$ - translation in $\mathrm{X}-\mathrm{T}_{\mathrm{x}}$

- $\operatorname{Trans}(\mathrm{Y})$ - translation in $\mathrm{Y}-\mathrm{T}_{\mathrm{y}}$

- $\operatorname{Trans}(\mathrm{Z})$ - translation in $\mathrm{Z}-\mathrm{T}_{\mathrm{Z}}$
- $\operatorname{Rot}(\mathrm{X})$ - rotation in $\mathrm{X}$ axis $-\mathrm{R}_{\mathrm{x}}$

- $\operatorname{Rot}(\mathrm{Y})$ - rotation in $\mathrm{Y}$ axis $-\mathrm{R}_{\mathrm{y}}$

- $\operatorname{Rot}(\mathrm{Z})$ - rotation in $\mathrm{Z}$ axis $-\mathrm{R}_{\mathrm{z}}$

If the robot respectively a manipulator designed for work in a space with full freedom of movement of the end platform or effector must have at least six degrees of freedom $T_{x}, T_{y}, T_{z}, R_{x}, R_{y}, R_{z}$.In the construction of a robot and a manipulator intended for work in the plane resp. three coordinates must be known for the specified working level. It is enough for us to know three degrees of freedom $T_{x}, T_{y}, R_{z}$.

Parallel robots can also be divided according to the number of degrees of freedom, as follows: 
- Universal robot - a robot that has all six degrees of freedom, is able to achieve any position and orientation in space.

- Redundant robot - has more than six degrees of freedom. Movement in any axis is enabled in several ways. Its use is especially suitable for circumventing obstacles and similar applications. The disadvantages associated with a higher number of degrees of freedom are: more demanding production, higher weight, more complex control algorithms, and complex route planning requiring precise control of all drives.

- Deficient robot - has less than six degrees of freedom. He cannot reach every position in the workspace. If it has three degrees of freedom, it can fully work only in the plane. [8][9]

\section{Types of parallel robots}

Parallel robots can be divided according to the shape of the workspace in which the effector or end platform moves into:

- Plane - its movement is allowed only within one plane, it has a maximum of three degrees of freedom (2T-1R). Guide chains can be swinging, sliding arms, ropes.

- Spatial - moves in 3D space, so the robot can have up to 6 degrees of freedom (3T-3R). Guide chains of various types.

- Spherical - can only perform a spherical motion relative to its base.

- Symmetric - a manipulator that has the number of guide chains equal to the number of degrees of freedom [10]

Parallel robots can also be divided according to the number of guide chains (arms) into groups they have (some types of parallel robots are shown in the pictures below):

- Six guide chains: - hexapod / linapod

- Five guide chains: - pentapod

- Three guide chains: - tripod / tricept / trivariant / exechon

- delta robot / triglid

- Two guide chains: - bipod

The most used and parallel robots and manipulators include:

\subsection{Gough-Stewart platform}

Gough-Stewart platform is a type of parallel manipulator constructed on the principle of hexapod according to the design of Dr. Eric Gough from 1965. The construction has six translational kinematic couplings, most often linear hydraulic or electric, electro-mechanical drives. All twelve connections are realized by means of universal joints (in the case of a cylindrical connection on actuators). The upper platform can move in up to six degrees of freedom, three linear movements Tx, Ty, Tz and three rotations Rx, Ry, Rz. On the Fig. 4 below is possible to see a kinematic structure and example of constructed Gough-Stewart platform. 


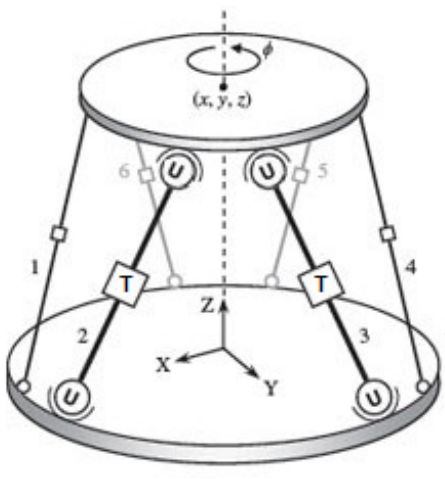

a)

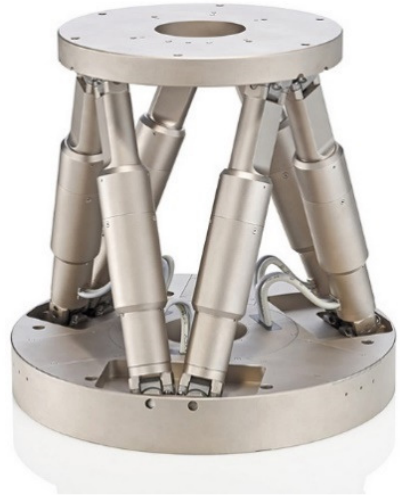

b)

Figure 4. Gough-Stewartova platform, a) kinematická štruktúra (MapleSoft, 2019), b) Gough-Stewartova platforma (Tempel, a iní, 2017)

This type of platform is also known by various other names. It has been used in several applications, including flight simulators built on the so-called "Movable base", from English "Moving base" [11], sometimes also "6-DoF platform" with regard to possible movements. The movements of the end member are created by a combination of the movements of several actuators. Because the device has six actuators, it is commonly called a hexapod, a name that was originally protected by Geodetic Technology's trademark for Gough-Stewart platforms used in machine tools.[12][7]

\subsection{Delta robot}

Delta robot is a type of parallel robot consisting of three arms, which are connected by universal joints on one base. Its main design feature is the use of parallelograms in the arm, which maintain a constant orientation of the end effectors. Delta robots can be used especially in the handling of components, for packaging and palletizing products, in the pharmaceutical, food and chemical industries. Since the delta robot drives are located on the base, it is possible to produce their arms with a very low weight, and therefore a very low inertia. They achieve high speeds and accelerations (up to $15 \mathrm{G}$ ), they can perform up to 300 operations in one minute.[13]

The first Delta robot was developed in the early 1980s by the Swiss prof. Reymond Clavel, who wanted to create a robot suitable for handling small and light objects at very high speeds. The Delta robot built by Reymond Clavel had three sliding and one rotating degree of freedom.[14] 


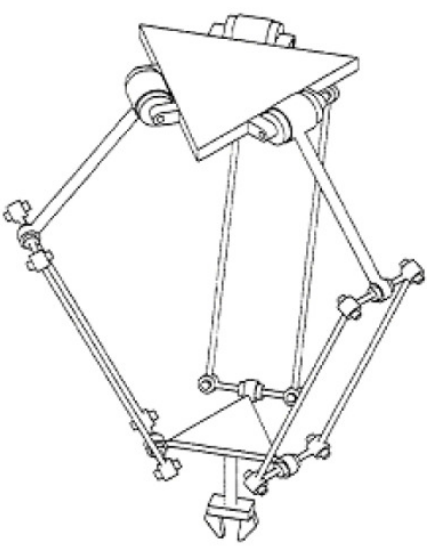

a)

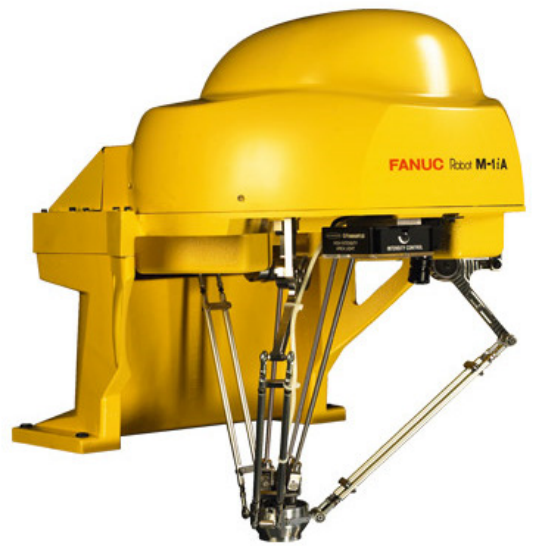

b)

Figure 5. Delta robot, a) prof. Clavel's Delta Robot Structure[15], b) Delta robot Fanuc M-1iA/0.5S [16]

\section{Advantages and disadvantages of parallet robots}

The introduction of parallel robots in industry is realized due to the number of advantages that parallel robots have compared to serial robots. Some of the benefits of parallel kinetic robots include:

- Load capacity, rigidity and accuracy - With regard to the overall rigidity, the load capacity of parallel robots tends to be significantly higher than the load capacity of serial robots.

- Excellent dynamic properties - the platform can achieve high speeds and accelerations. In addition, the resonant frequency of the parallel robot is an order of magnitude higher.

- Simple construction - several passive connections in parallel robots allow cheaper and simpler mechanical construction. When building parallel robots, it is possible to use standard bearings, spindles and other machine elements.

Despite a number of advantages, the use of parallel robots is partially limited. Due to the solid shape and position of the base, a parallel robot can have complicated maneuvering and avoiding obstacles in its workspace.

Other disadvantages include:

- Small workspace - Parallel robots have significantly smaller workspaces than serial robots of comparable size. Their working space can be further reduced, as the legs can interfere with each other during the movement of the platform.

- Complex kinematics - Calculating the kinematics of parallel robots is complicated and time consuming. Unlike serial robots, where difficulties arise in solving an inverse kinematic problem, in parallel mechanisms difficulties arise in solving a direct kinematic problem. 
- Kinematic singularities - serial robots in kinematically singular poses loses mobility. Parallel robots in singular poses gain degrees of freedom, due to which they cannot be controlled at these certain points of the workspace. This is one of the situations that is very difficult to solve.[6]

\subsection{Areas of application and usage of parallel robots}

The industrial sphere is probably the most important in terms of the use of parallel kinematic structures. Of course, parallel kinematic robots did not push serial kinematic robots out of the industrial robot market, but thanks to its advantages such as mainly rigidity and very good dynamics, they found their application. A large number of variants of construction of parallel structures also offer a wide range of applications. The main areas of application of parallel kinematics include:

- machining - use as machine tools and centers,

- handling operations - "pick and place" robots,

- forming machines,

- measuring machines,

- test equipment,

- simulation devices,

- pharmaceutical and medical facilities,

- rehabilitation aids,

- end effectors of other production equipment,

- equipment specially designed for space applications.

According to the purpose, industrial robots and manipulators can be divided into several groups, namely performing robots[17]:

- Technological operations:

- $\quad$ spot welding (Fanuc Robotic - F200i),

- laser welding (Neos Robotic- Tricept 805),

- water jet machining (Fooke - Triomaxx),

- deburring of castings (MutiCraft - MultiCraft 560),

- wood processing (Reichenbacher - Pegasus).

- Handling and assembly operations:

- manipulator (SMT Tricept - TM 805, TR 600),

- positioning of samples under microscopes (Hexel - Hexabot; Physik Instrumente - M 805; Israel Institute of Technology - RSPR3 mini-parallel robot),

- positioning of the workpiece and its fixtures (Umformtechnik ERFURT TAS Hexapod),

- storage of SMD components on printed circuit boards (ABB - FlecPicker),

- positioning of optical elements, e.g. cameras (Laval University - Agle Eye),

- positioning of simulator platforms (CAE-Flight simulators - AH-I, S-70),

- Assembly operations (Festo - Delta robot; SMT Tricept - TR 600).[18] 


\section{Conclusion}

The article deals with an overview of parallel kinematics robots their architecture and usage in industry. Also kinematics and their parts are described. The comparison with serial robots is made. In the future is expected that parallel robots will be increasingly implemented in industry. These robots can replace serial kinematics robots in certain applications. But the development is still

\section{ACKNOWLEDGEMENT}

This work was supported by the grant agency KEGA, project no. 042ŽU-4/2020 Building up a specialized laboratory for mechatronic systems to improve the teaching of the newly-accredited subject Mechatronic Systems; and by Grant System of University of Zilina No. 1/2021 (14892).

\section{REFERENCES}

1. WILLIAMS B.:An Introduction to Robotics in Catalonia, Catalònia, no. 23, pp. 28-29-29, 1991, [Online]. Available: https://www.ohio.edu/mechanicalfaculty/williams/html/PDF/IntroRob.pdf.

2. POPPEOVÁ V, BULEJ V., REJDA R.: Serial, parallel and hybrid kinematic structures of production machines and robots, The13th International Scientific Conference Trends and Innovative Approaches in Business Processes, 2010.

3. REJDA R.: Návrh programového vybavenia pre paralelné kinematické štruktúry s rôznym počtom stupňov vol'nost, Žilinská Univerzita v Žiline, 2010.

4. MERLET, J. P.: Parallel robots. Second Edition. Springer, 2006, pp.327, ISBN 0-4020-4132-2.

5. GOUBEJ M., ŠVEJDA M., SCHLEGEL M.: Uvod do mechatroniky, robotiky ' a syst'em 'u 'r'1zen'1 pohybu, May 2012.

http://home.zcu.cz/ msvejda/URM/materialy/Uvod do mechatroniky.pdf (accessed Nov. 03, 2021).

6. MIHELJ M.et al.: Parallel Robots, Solid Mech. its Appl., vol. 128, pp. 69-83, 2019, doi: 10.1007/978-3-319-72911-4_6.

7. TAGHIRAD H.: Parallel robots : mechanics and control. CRC Press; 1 st edition , 2013.

8. ŠKKARUPA J.: Průmyslové roboty a manipulátory: učební text. ysoká škola báňská, Technická univerzita Ostrava, 2007.

9. ČERNOHORSKÝ J.: Základy robotiky: Kinematika a togologie robotů. Technická univerzita v Liberci: Fakulta mechatroniky, informatiky a medzioborových studií., 2012.

10. PATEL Y. D., GEORGE P. M., PATEL Y. D., GEORGE P. M.: Parallel Manipulators Applications-A Survey, Mod. Mech. Eng., vol. 2, no. 3, pp. 5764, Aug. 2012, doi: 10.4236/MME.2012.23008. 
11. BECERRA-VARGAS M., MORGADO BELo E.: Application of Hœ theory to a 6 DOF flight simulator motion base, J. Brazilian Soc. Mech. Sci. Eng., vol. 34, no. 2, pp. 193-204, Apr. 2012, doi: 10.1590/S1678-58782012000200011.

12. NIESING B., "Robots for Spine Surgery," Med. Eng., vol. 2, 2001, [Online]. Available:

http://www.fraunhofer.delfhg/archiv/magazin/pflege.zv.fhg.delenglish/publicati ons/df/df2001/magazine2_2001_46.pdf.

13. Zbíralová K.: Co je to Delta robot a jak funguje? https://factoryautomation.cz/delta-robot-jak-funguje/ (accessed Nov. 03, 2021).

14. FANUC Czech s.r.o, "Čo je to Delta robot a ako funguje? | FANUC DailyAutomation." https://www.dailyautomation.sk/delta-robot/ (accessed Nov. 03, 2021).

15. Staicu S., Carp-Ciocardia D. C.: Dynamic analysis of Clavel's delta parallel robot, Proc. - IEEE Int. Conf. Robot. Autom., vol. 3, pp. 4116-4121, 2003, doi: 10.1109/ROBOT.2003.1242230.

16. Fanuc - Prehl'ad sortimentu robotov FANUC https://www.fanuc.eu/sk/sk/robots/robot-range-page (accessed Nov. 03, 2021).

17. Singule V., Knoflíček R., Synek M., Szabó I., Bartoš S.: Simulation of the mobile robot system operation, in Advanced Engineering Design 2006, 2006, p. 1.

18. Rupíkova M.: Štúdium vybraných prevádzkových parametrov mechanizmu s paralelnou kinematickou štruktúrou, Žilinská univerzita v Žiline, 2012. 
